\title{
Partnership for Health Development through the Field Practice
}

\author{
Jonathan P. Guevarra, ${ }^{1}$ Maribel G. Oidem, ${ }^{2}$ Josue Antonio G. Estrada, ${ }^{2}$ Arlene G. Bertuso, ${ }^{3}$ \\ Maridel P. Borja, ${ }^{4}$ Ernani R. Bullecer, ${ }^{5}$ Teresita S. de Guzman ${ }^{6}$ Lydia R. Leonardo ${ }^{3}$, Victorio B. Molina ${ }^{7}$ \\ Ma. Susan T. Yanga- Mabunga ${ }^{8}$, Eleanor C. Castillo, ${ }^{1}$ Paul Michael R. Hernandez, ${ }^{7}$ \\ Ma. Socorro E. Ignacio, ${ }^{5}$ Richard S. Javier, ${ }^{8}$ Paul Adrian V. Pinlac ${ }^{4}$ and Evalyn A. Roxas ${ }^{6}$ \\ ${ }^{1}$ Department of Health Promotion and Education, College of Public Health, University of the Philippines Manila \\ ${ }^{2}$ College of Public Health, University of the Philippines Manila \\ ${ }^{3}$ Department of Parasitology, College of Public Health, University of the Philippines Manila \\ ${ }^{4}$ Department of Epidemiology and Biostatistics, College of Public Health, University of the Philippines Manila \\ ${ }^{5}$ Department of Nutrition, College of Public Health, University of the Philippines Manila \\ ${ }^{6}$ Department of Medical Microbiology, College of Public Health, University of the Philippines Manila \\ ${ }^{7}$ Department of Environmental and Occupational Health, College of Public Health, University of the Philippines Manila \\ ${ }^{8}$ Department of Health Policy and Administration, College of Public Health, University of the Philippines Manila
}

\begin{abstract}
This article describes the partnership between the College of Public Health, University of the Philippines Manila and the province of Laguna in the context of the implementation of the field practice course. This partnership paved the way for the development and implementation of projects in seven field practice sites. Projects concentrated mainly on improving quality of data and health information system, development of educational materials, and addressing health problems such as tuberculosis, hypertension and rabies. After the implementation of the various activities, there is a need for both parties (the College of Public Health and the Provincial Health Office of Laguna) to monitor and evaluate if projects have been sustained. Moreover, successful projects must also be fully documented which can serve as models for other areas in the province of Laguna.
\end{abstract}

Key Words: partnership, field practice, College of Public HealthUniversity of the Philippines Manila, Provincial Health Office of Laguna, Philippines, monitoring and evaluation

\section{Background}

In 1927, the College of Public Health (CPH) was established as a unit of the University of the Philippines committed to the training of medical officers in the Philippine Health Service. Originally called the School of Sanitation and Public Health, $\mathrm{CPH}$ has undergone several transformations over the years, becoming the School of

Corresponding author: Jonathan P. Guevarra, RN, RM, MAN

Department of Health Promotion and Education

College of Public Health

University of the Philippines Manila

625 Pedro Gil Street, Ermita, Manila 1000 Philippines

Email: jpguevarra2@up.edu.ph
Hygiene in 1929, Institute of Hygiene in 1938, Institute of Public Health in 1971, and, finally, the College of Public Health in 1986. ${ }^{1}$ In 1965, the Southeast Asian Ministers of Education Organization (SEAMEO) designated CPH as the National Center for Public Health. In 1993, it was designated by SEAMEO as the Regional Center for Public Health, Hospital Administration and Environmental and Occupational Health ${ }^{1}$. Through the years, $\mathrm{CPH}$, with its faculty, staff, and students, has engaged itself in community service through various academic and non-academic activities. Public Health 280 (PH 280) or the Field Practice, a core course in the Master of Public Health (MPH) Program of $\mathrm{CPH}$, is one of the many channels by which $\mathrm{CPH}$ has extended service to different communities in the country.

The Field Practice course is the advanced practice in the field of public health wherein students apply different concepts, principles, and techniques in various aspects of public health. It is a three-unit course conducted jointly by all departments of $\mathrm{CPH} .^{2}$ Through the collaborative efforts of $\mathrm{CPH}$ and its partner communities, the course is expected to improve the health status of the people while providing relevant training to health professionals. It has been implemented in several areas in the Philippines including the provinces of Rizal, Bulacan, Cavite, and Laguna.

Laguna has long been a partner province of the College. In 2005, an 8-year partnership between $\mathrm{CPH}$ and the Province of Laguna was forged. This 2014, a new five-year Memorandum of Agreement (MOA) was signed between the College of Public Health - University of the Philippines Manila (CPH-UPM) and the Province of Laguna, represented by the Provincial Health Office of Laguna (PHO-Laguna), to sustain this partnership through the implementation of the $\mathrm{PH} 280$ - the field practice course. ${ }^{3}$

In a forum in 2008, campus-community partnership was defined as a "collaborative and dynamic relationship between parties working toward and achieving shared goals while 
respecting individual differences". ${ }^{4}$ The process of establishing community-university partnerships is likened also into merging the different worlds of the academe and the community where people have different views on knowledge. ${ }^{5}$

A "community-higher education" partnership focuses on quality processes, meaningful outcomes and transformation at individual, institutional and social level. The process of community-campus partnership starts from designing it with a common shared vision and sense of being beneficial to each partner, then establishing the work relationships among partners with trust and mutual respect, and finally ensuring the long-term function of the partnership. ${ }^{6}$

A partnership between the academe and a community may be bound by a process. In the case of $\mathrm{PH} \mathrm{280,} \mathrm{this}$ process involves formulating and implementing specific strategies and activities to respond to the different health issues in the community. Figure 1 shows a general framework that describes how PH 280 is implemented. As seen in the figure, the conduct of PH 280 involves a series of steps undertaken by both the academe and the community. Several benefits are expected to result from the process. For the community, the partnership is expected to improve the quality of health services through systems development, capacitate the local health unit, and empower the communities through the development of well-designed 'people-oriented' health projects. The academe, on the other hand, is expected to benefit from the partnership through the development of students' and faculty's capacity as health professionals, and the further improvement of program and course offerings.

This article aims to describe the partnership for health development between the College of Public Health and the Province of Laguna in the context of the implementation of the field practice course in 2014. It also presents important experiences (opportunities and challenges) of both parties in the conduct of the said course.

The PH 280 Experience: Process used in the Implementation of the New Partnership

In the summer of 2014, the partnership for health development through the Field Practice Course was jointly implemented by CPH (through the PH 280 Committee) and the Province of Laguna, Philippines (through the Provincial Health Office of Laguna). Figure 1 shows the process undertaken for this partnership.

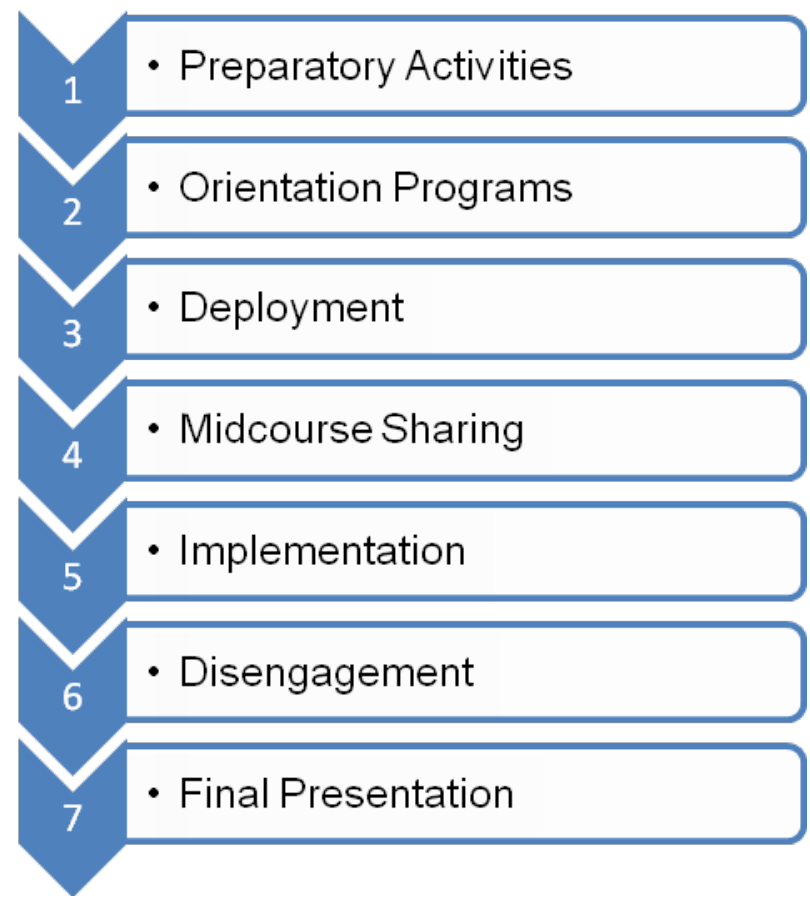

Figure 1. The Process in the Implementation of the Partnership through the Field Practice.

\section{Preparatory Activities}

The success of an academe-community partnership relies heavily on good rapport and mutual trust established between the parties. For this to happen, consultative meetings between the two institutions were conducted starting 1st Semester of Academic Year 20132014. The PH 280 Committee of $\mathrm{CPH}$ (composed of faculty members from each of the seven departments of the college) met several times to craft the mechanics and policies for the implementation of the field practice course now contained in the PH 280 Manual. To ensure its relevance to both parties, inputs, comments and suggestions were obtained through meetings with the Provincial Health Office (PHO). These were incorporated in the final version of the $\mathrm{PH} 280$ manual which served as the main reference of the field practice course for Summer 2014. Meanwhile, a Memorandum of Agreement (MOA) was signed by both parties in February 2014 which made the 5-year partnership between the two institutions official.

\section{Orientation Programs}

The PH 280 Committee members (composed of faculty preceptors), field preceptors (composed of the municipal and city health officers) and field coaches (composed of officials from the Province of Laguna), underwent orientation separately and with the Master 
of Public Health (MPH) students enrolled in the field practice course. The purpose of the orientation programs was to provide a common understanding of the mechanics of the field practice course and the partnership among the various groups. For the students and faculty preceptors, the orientation program involved team-building activities aimed at establishing good working relationships among groups. The orientation program between $\mathrm{CPH}$ and $\mathrm{PHO}$ Laguna, on the other hand, involved interactive activities where both parties were able to share their expectations and goals for the course.

\section{Deployment}

Students were deployed in various areas in the Province of Laguna on the first day of their six-week field practice course. After deployment, students conducted situational analyses of their assigned areas with various stakeholders in the field (health officials, local government officials and other sectoral groups) for the first two weeks of their stay. A project plan was developed by the stakeholders with the assistance of the faculty and field preceptors.

\section{Midcourse Sharing}

The midcourse sharing, a collaborative activity between $\mathrm{CPH}$ and Laguna, was done on the third week. This included presentations of the situational analysis and the project plan of each group. Inputs, comments and suggestions from fellow students, faculty, field preceptors and representatives of the community were sought in order to clarify issues and refine their project plans.

\section{Implementation}

Implementation is the phase wherein strategies and activities are carried out in the field practice site. Once the project plan is finalized, implementation of various activities was done for three weeks.

\section{Disengagement}

Disengagement was done on the last day of the students' stay in their field practice sites. Students presented the project's accomplishments and endorsements for activities. In most instances, agreement or pledge of commitment is forged among various stakeholders to sustain the project initiated in the site.

\section{Final Presentation}

The final presentation, held at the College of Public Health, was marked by the students' presentation of their accomplishments and field experiences to the field stakeholders, faculty, field preceptors and fellow students.

\section{Projects Implemented Through the Field Practice}

For the 2014 field practice, the different groups deployed in specific areas in Laguna developed and implemented projects focusing on several areas. Detailed in Table 1 are the projects implemented by the students and the community stakeholders.

\section{Opportunities and Challenges in the Implementation of the Renewed Partnership}

The new MOA with the province of Laguna signalled the renewal of another 5-year partnership that can benefit both the community and academe. The projects implemented are the results of collaborative efforts exerted by the various stakeholders. These projects once again provided the opportunity for each community to have their current health and health-related issues addressed. The formulation of the health projects considered community ownership hence it is hoped that the efforts started will be sustained.

One important aspect worth noting is the active involvement of various stakeholders. Both the academe (represented by the faculty preceptors and the students) and local stakeholders (represented by the health officials and community leaders) made substantial contributions from the planning to the implementation phase. These contributions provided valuable inputs for the formulation of relevant health projects which garnered support from the people in the community.

The course evaluation for $\mathrm{PH} 280$ also provided inputs for the further improvement of the implementation of the course. For example, both the students and the community felt that the field practice exposure was too short for the planning and implementation of projects. Increasing the time for the field exposure (in terms of number of weeks) will provide more learning experiences/opportunities to students. Likewise, it could provide more time to refine the projects and extend the scope of the projects to a larger portion of the community. This is a recommendation that can be considered by the $\mathrm{CPH}$ during the evaluation and enhancement of the MPH curriculum.

Challenges were also noted during the implementation of the partnership. One of the major challenges is "sustainability" of the projects. This involves ensuring the continuous support of various stakeholders in the community to sustain the efforts implemented in the field practice sites. This 'challenge' also underscores the need for monitoring and evaluation activities. Both $\mathrm{CPH}$ and $\mathrm{PHO}$ Laguna should be sufficiently involved in the monitoring and evaluation of the projects. The conduct of a collaborative assessment can provide information both on pitfalls in the project implementation and on the successful projects which can serve as models for other communities in the province of Laguna. 
Table 1. Projects Implemented through the Field Practice, 2014

\begin{tabular}{|c|c|c|}
\hline Area & Project Title & Key Accomplishments \\
\hline Bay & $\begin{array}{l}\text { "GoodBAY TB! ETong Sa 'Yo!” (Increasing the TB Cure Rate in } \\
\text { Bay through E-ducation and T-exting): Increasing TB Cure Rate } \\
\text { in Bay through Education and Texting7 }\end{array}$ & $\begin{array}{l}\text { Conduct of reorientation seminar on NTP ID and } \\
\text { treatment cards for BHWs } \\
\text { Conduct of training of local health staff on TB } \\
\text { counselling } \\
\text { Creation of a TB SMS reminder system for patients } \\
\text { enrolled in the TB DOTS program } \\
\text { Lobbying of municipal ordinance to adapt a provision } \\
\text { of the Philippine Pharmacy Law regarding the proper } \\
\text { dispensing of anti-TB drugs }\end{array}$ \\
\hline Calamba City & $\begin{array}{l}\text { FAMILY PLANNING AY PALAWIGIN, PAGKALAP NG } \\
\text { TAMANG IMPORMASYON PAGTIBAYIN! Strengthening } \\
\text { Community-Based Information System for Effective Delivery of } \\
\text { Family Planning Services }^{8}\end{array}$ & $\begin{array}{l}\text { Establishment of recording and data reporting system } \\
\text { for family planning services. }\end{array}$ \\
\hline Magdalena & $\begin{array}{l}\text { Project PITA (Pulidong Impormasyon Tungo sa Aksyon): } \\
\text { Improving the Quality of Data of the Maternal and Newborn } \\
\text { Healthcare in the Rural Health Unit (RHU) of Magdalena, } \\
\text { Laguna }^{9}\end{array}$ & $\begin{array}{l}\text { - } \quad \text { Conduct of Basic Information Management Training } \\
\text { - } \quad \text { Creation of Health Information Board } \\
\text { - Organization of the "information flow" in the RHU }\end{array}$ \\
\hline Pagsanjan & $\begin{array}{l}\text { PINAGPALAng BHWs: Pinatatag na Gabay para sa Pagsanjan, } \\
\text { Laguna BHWs }{ }^{10}\end{array}$ & $\begin{array}{l}\text { Formulation of MNCHN Handbook for BHWs } \\
\text { Training of BHWs on MNCHN using the handbook } \\
\text { and rolling this training out to other barangays and } \\
\text { municipalities } \\
\text { Organization of the data handling processes in the } \\
\text { RHU }\end{array}$ \\
\hline Pila & $\begin{array}{l}\text { “TAMANG EDUKASYON AT MEDIKASYON PARA } \\
\text { LABANAN ANG ALTA-PRESYON" : A community Health } \\
\text { project on Hypertension at Pila, Laguna" }{ }^{11}\end{array}$ & $\begin{array}{l}\text { - Conduct of Training on Hypertension Control and } \\
\text { Prevention for BHWs and CHTs } \\
\text { Barangay advocacy campaign for the promotion of } \\
\text { healthy lifestyle. }\end{array}$ \\
\hline San Pablo City & $\begin{array}{l}\text { Improving Tuberculosis (TB) Case Detection Rate (CDR) } \\
\text { through Advocacy, Communication and Social Mobilization } \\
\text { Strategies in San Pablo City }{ }^{12}\end{array}$ & $\begin{array}{l}\text { - Training of trainers for the Basic TB Course } \\
\text { Information dissemination through the house-to- } \\
\text { house distribution of IEC materials } \\
\text { Initiation of Active TB case finding }\end{array}$ \\
\hline Sta. Cruz & $\begin{array}{l}\text { Bantay Mo, MAHALIN MO: OPLAN ARF ARF } \\
\text { All Rabies Free by the Year } 2016 \text { through the Anti-Rabies Force }{ }^{13}\end{array}$ & $\begin{array}{l}\text { Lobbying of Barangay Ordinance for the creation of } \\
\text { Rabies task force in each barangay. } \\
\text { Awareness campaign through the distribution of IEC } \\
\text { materials and conduct of a project lunching activity } \\
\text { which involved the community residents } \\
\text { Development of Dog Registration System }\end{array}$ \\
\hline
\end{tabular}

\section{Acknowledgments}

The authors would like to acknowledge UP Manila Chancellor Dr. Manuel B. Agulto, College of Public Health Dean Romeo R. Quizon, Laguna Governor Emilio Ramon "E.R." Ejercito, the Laguna Provincial Health Office Officials (Dr. Judy Rondilla, Dr. Ronaldo Catindig and Ms. Rachel Daoa), and Municipal/City Health Officers, for all the support extended on this partnership. We also appreciate the dedication of the Field Preceptors and Field Coaches and the various community stakeholders for actively participating in the process of implementing the partnership. Lastly, we would like to commend the students for exerting their best efforts in partnering with various community stakeholders in delivering meaningful health projects for the people of Laguna.

\section{References}

1. College of Public Health, University of the Philippines Manila. Catalogue 2007-2010. p. 2

2. College of Public Health, University of the Philippines Manila. PH 280 Manual 2014. p.5

3. Memorandum of Agreement. University of the Philippines Manila and Province of Laguna, February 2014.

4. Portland State University. A Guide to Reciprocal Community-Campus Partnerships. Proceedings from Portland State University's Partnership Forum, March 6-8, 2008, pp. 2-5. [Online]. 2008 [cited 2014 April]. Available from https://depts.washington.edu/ccph/pdf_files/Guide_ corrected_041808.pdf

5. Sandy M, Holland B. Different worlds and common ground: Community partner Perspectives on campus-community partnerships. Michigan Journal of Community Service Learning, pp. 30-43. [Online]. 2006 [cited 2014 April]. Available from http://files.eric.ed.gov/ fulltext/EJ843845.pdf

6. Torres J, Schapper J. Benchmarks for Campus/Community Partnership, pp 101-103. [Online] 2000 [cited 2014 April]. Available from http://www.virginia.edu/provost/public/pdf/benchmarks.pdf 
7. Diomampo Cecilio P, Liao Maria Josephine G, Ora Andrea Margreth S, Policarpio Judea Marie, Ramas Ryan R, Salamat Maria Sonia S. "GoodBAY TB! ETong Sa 'Yo!" (Increasing the TB Cure Rate in Bay through E-ducation and T-exting) (Bay, Laguna). College of Public Health, University of the Philippines Manila, May 2014. PH 280: Field Practice Report.

8. Alindogan Mark Anthony, Asuncion Wendell S, Calpito Mercedes S, Fragante Naja F, Ramos Paolo D, Rubico Faye Marjorie C. FAMILY PLANNING AY PALAWIGIN, PAGKALAP NG TAMANG IMPORMASYON PAGTIBAYIN! Strengthening Community-based Information System for Effective Delivery of Family Planning Services (Calamba, Laguna). College of Public Health, University of the Philippines Manila, May 2014. PH 280: Field Practice Report.

9. Claracay Weby C, Culla Charisma S, Romana-Bantiles Maria Daniela S, Valdescona Mikhail A, Valdez Jason Roland N, Zamora Arianne A. Project PITA (PulidongImpormasyonTungosaAksyon): A project to improve the quality of data for maternal and newborn healthcare in the Rural Health Unit (RHU) of Magdalena, Laguna. College of Public Health, University of the Philippines Manila, May 2014. PH 280: Field Practice Report.

10. Arandia Joyce Ann M, Chamen Iza Mae S, Macaraan Jenny Christy R, Retiban Pearl Joy B, San Andres Neil G. PINAGPALAng BHWs: PINAtatagnaGabayPArasaPagsanjan, LAguna Barangay Health Workers (Pagsanjan, Laguna). College of Public Health, University of the Philippines Manila, May 2014. PH 280: Field Practice Report.
11. Daluz Olivia, Egargo Jesus N, Grullo Precious R, Martinez Rhianna G, Usal Ben Gerald D. "TAMANG EDUKASYON AT MEDIKASYON PARA LABANAN ANGALTA-PRESYON" : A Community Health Project on Hypertension at Pila, Laguna. College of Public Health, University of the Philippines Manila, May 2014. PH 280: Field Practice Report.

12. Baltasar Jacqueline, Briones Adrian Noel, Cadag Ma. Cristina, Manlutac Maricelle, Quintana Ronaldo, Roxas Ivy. Improving Tuberculosis (TB) Case Detection Rate (CDR) through Advocacy, Communication, and Social Mobilization Strategies in San Pablo City. College of Public Health, University of the Philippines Manila, May 2014. PH 280: Field Practice Report.

13. Barcenas Titus John, Bautista Bernadette, Hernandez Sandra, Inano Ma. Eloisa, Parrocha Verna, Pestano, Arnold. Bantay Mo, MAHALIN MO: OPLAN ARF ARF (All Rabies Free by the year 2016 through Anti-Rabies Force). College of Public Health, University of the Philippines Manila, May 2014. PH 280: Field Practice Report.

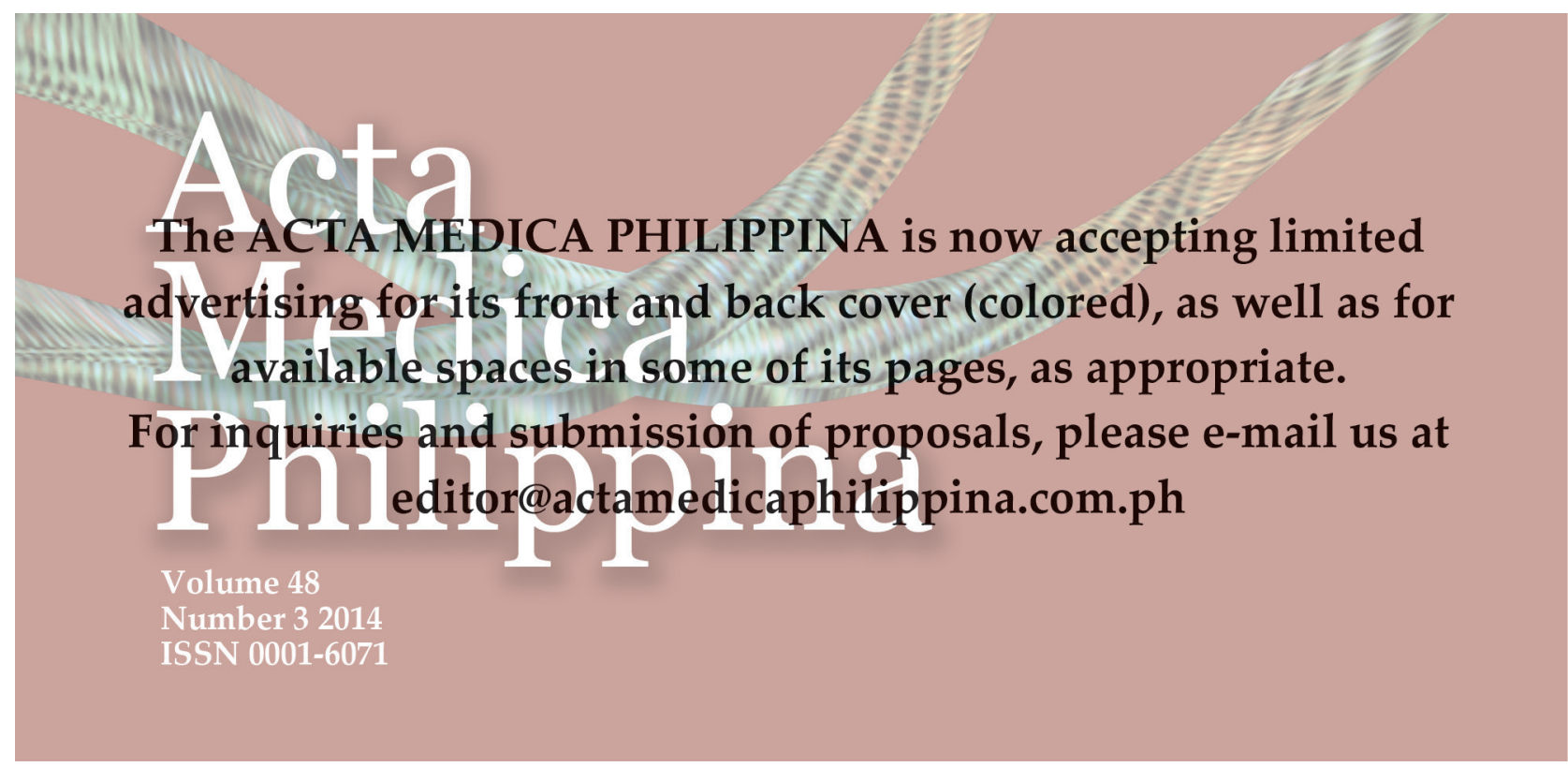

